\title{
Melatonin concentration in the milk of cows supplemented with vitamins and milked twice daily
}

\section{Concentração de melatonina no leite de vacas suplementadas com vitaminas e dois horários de ordenha}

\author{
Vitória Maria Montenegro Holzmann ${ }^{1}$; Milena Trentin ${ }^{1}$; Fabíola Cristine de \\ Almeida Rego ${ }^{2}$; Luiz Fernando Coelho Cunha Filho²; Agostinho Ludovico ${ }^{3 *}$
}

\section{Resumo}

\begin{abstract}
Melatonina é um hormônio secretado no leite e tem efeitos benéficos sobre a saúde humana. Este estudo objetivou avaliar os efeitos da suplementação da dieta com vitaminas e da ordenha noturna sobre a concentração de melatonina no leite de vacas. Foram utilizadas 21 vacas confinadas, na fase final de lactação e as vitaminas suplementadas foram do complexo $\mathrm{B}$, vitaminas $\mathrm{A}, \mathrm{D}_{3}$ e $\mathrm{E}$ rúmen-protegidas, sendo a niacina (B3) não protegida da degradação ruminal. O período experimental teve duração de 10 dias, as amostras de leite foram coletadas nos dois primeiros dias, sem suplementação de vitaminas (SEM) e nos dois dias finais, oito dias após início da suplementação (COM). Foram analisadas amostras do leite produzido sem e com suplementação, nas ordenhas realizadas às 05:00 h (NOITE) e do leite total produzido nas duas ordenhas diárias (TOTAL). A concentração de melatonina foi determinada através de imunoensaio enzimático em kit de ELISA e os resultados analisados ANOVA e teste Tukey com 5\% significância. A suplementação da dieta COM vitaminas não teve efeitos sobre a concentração de melatonina no leite TOTAL, porém, no leite da NOITE, resultou em concentração 40,55\% menor que o leite de vacas SEM suplementação (6,57 vs 11,06 $\mathrm{pg} \mathrm{mL}^{-1}$, respectivamente). O leite da ordenha da NOITE apresentou concentração de melatonina 1,43 a 2,38 vezes superior ao leite TOTAL diário. $\mathrm{O}$ leite total do rebanho apresentou concentração de $2,13 \mathrm{pg} \mathrm{mL}^{-1}$. A coleta diferenciada do leite produzido no período noturno possibilita a obtenção de leite com alta concentração de melatonina.
\end{abstract}

Palavras-chave: Leite da noite. Niacina. Vitaminas B. Rúmen-protegida. Composição.

\begin{abstract}
Melatonin, a hormone secreted in cow milk, has beneficial effects on human health. This study aimed to evaluate the effects of dietary vitamin supplementation and nocturnal milking on the concentration of melatonin in cow milk. Twenty-one confined cows in the final period of lactation were used for the study and the supplemented vitamins were: rumen-protected B vitamins, A, $\mathrm{D}_{3}$, E, and niacin (B3) not protected from rumen degradation. The experimental period had a duration of 10 days. Milk samples were collected during the first two days, without supplementation of vitamins (WITHOUT), and during the final two days, eight days after the beginning of supplementation (WITH). Samples of milk produced without and with supplementation, milked at 05:00 h (NIGHT) or from the total milk produced in

\footnotetext{
1 Discentes, Curso de Mestrado, Programa de Pós-Graduação em Ciência e Tecnologia de Leite e Derivados, Universidade Pitágoras Unopar, Campus Piza, Londrina, PR, Brasil. E-mail: toiamontenegro@yahoo.com.br; milenatrentin@hotmail.com.br

2 Profs., Mestrado em Saúde e Produção de Ruminantes, UNOPAR, Arapongas, PR, Brasil. E-mail: fabiolaregogrecco@gmail. com; luiz.cunha@unopar.br

3 Prof., Mestrado em Ciência e Tecnologia de Leite e Derivados, UNOPAR, Campus Piza, Londrina, PR, Brasil. E-mail: agostinho@rocketmail.com

* Author for correspondence
} 
the two daily milkings (TOTAL), were analyzed. The concentration of melatonin was determined by enzyme immunoassay using the ELISA kit, and the results were analyzed by ANOVA and Tukey's test with 5\% significance. Supplementation of the diet with vitamins (WITH) did not affect melatonin concentration in TOTAL milk, but it resulted in a concentration $40.55 \%$ lower in the NIGHT milk than in the milk from cows without (WITHOUT) supplementation (6.57 vs. $\left.11.06 \mathrm{pg} \mathrm{mL}^{-1}\right)$. Milk milked at night showed melatonin concentrations 1.43 to 2.38 times higher than daily TOTAL milk. The total milk of the herd showed a concentration of $2.13 \mathrm{pg} \mathrm{mL}^{-1}$. The differentiated collection of milk produced during the night period makes it possible to obtain milk with high levels of melatonin.

Key words: Night-milk. Niacin. B vitamins. Rumen-protected. Composition.

\section{Introduction}

Consumers increasingly seek additional benefits through the consumption of food, besides the nutrients it provides. This includes cow milk consumption, because, besides its nutrients (WIJESINHA-BETTONI; BURLINGAME, 2013), it contains several other beneficial components to health known as functional components (BHAT; BHAT, 2011; STANTON et al., 2013). These include melatonin, which is a hormone produced primarily by the pineal gland and secreted in milk, with a regulatory effect on the circadian cycle and sleep, and antioxidant and antitumor functions, among others (DI BELLA et al., 2013).

Melatonin biosynthesis is performed in the absence of light (HOFMAN et al., 1995) from the essential amino acid tryptophan (in the same biochemical pathway of the serotonin synthesis), in a sequence of reactions dependent on enzymes and organic and inorganic cofactors. Research regarding the effects of nutrients on the synthesis of melatonin has generally been carried out with rats and humans and has shown positive results concerning the role of vitamins, minerals, and polyunsaturated fatty acids on the production of melatonin (PEUHKURI et al., 2012).

Nicotinamide, generally known as niacin, is a vitamin also synthesized in the tryptophan metabolism (RICHARD et al., 2009). In tissues, nicotinamide is converted into nicotinamide adenine dinucleotide (NAD) and nicotinamide adenine dinucleotide phosphate (NADP), which are essential coenzymes for energy and lipid metabolism, functioning as electron acceptors in catabolic reactions or as electron donors in anabolic reactions (MARIA; MOREIRA, 2011). The synthesis of niacin from tryptophan is controlled through a negative feedback mechanism, where an adequate level of niacin inhibits its synthesis from tryptophan. Thus, increased intestinal absorption of niacin decreases the use of tryptophan in its synthesis and makes this amino acid available for the synthesis of melatonin (DAWN et al., 2009; MARIA; MOREIRA, 2011).

In ruminants, the organic components of the diet, including water-soluble vitamins not protected from ruminal degradation, are intensely degraded by the ruminal microbiota. However, this same ruminal microbiota also synthesizes water-soluble vitamins, usually making it unnecessary to supplement them for ruminants. Seemingly, $80-90 \%$ of dietary niacin is degraded in the rumen, and its synthesis at this site does not adequately compensate for this degradation (SANTSCHI et al., 2005).

The synthesis of melatonin is strongly dependent on the level of illuminance and photoperiod. Muthuramalingam et al. (2006) detected that illuminances of up to 5 and 10 lux do not inhibit the synthesis of melatonin, while Valtonen et al. (2001) observed a melatonin increase from $10 \mathrm{pg} \cdot \mathrm{mL}^{-1}$ to 60 pg. $\mathrm{mL}^{-1}$ in cow milk when they increased the dark period from 12 to 17 hours.day ${ }^{-1}$.

The present study aimed to determine the effects of dietary supplementation and milking time on the concentration of melatonin in cow milk produced by a commercial herd in Paraná State, Brazil. 


\section{Material and Methods}

The experiment was carried out in December 2017 at a commercial dairy farm in the municipality of Castro, Paraná State, Brazil. The local climate is temperate and classified as $\mathrm{Cfb}$ according to Köppen's classification. Twenty-one Holstein cows were used, with $62.41 \pm 19$ months of age, $2.77 \pm$ 1.48 lactations, $357 \pm 129$ days in lactation, estimated production of $11,602 \pm 1,980 \mathrm{~kg}$ in 305 days of lactation, and $68.18 \%$ with confirmed pregnancies. Cows were kept in free-stall confinement with a height of $5.5 \mathrm{~m}$, zinc-aluminum cover with a central opening, and sand stalls.

During the experimental period, the cows remained without artificial lighting at night. For the monitoring of the illuminance inside the free-stall stable, a portable MLM-1020 (Minipa do Brasil Ltda, São Paulo, Brazil) lux meter was installed and equipped with a digital visible light sensor (3\% of accuracy) and an automatic data logger recording at 4-min intervals. The equipment was fixed to a height of $1.5 \mathrm{~m}$ from the floor next to the stalls. Feed was provided ad libitum in two daily meals, with an average consumption of $20.96 \mathrm{~kg}^{-d_{a y}{ }^{-1} \text { of }}$ dry matter (DM) and leftovers of 140 g. $\mathrm{kg}^{-1}$ of the natural material supplied. The diet was formulated to meet the nutritional requirements of the animals. The ingredients and nutrient composition of the diet are described in Table 1.

Table 1. Daily consumption (kg DM.cow $\left.{ }^{-1}\right)$ and contents (\% of DM) of ingredients and nutrients in the experimental diet without supplementation.

\begin{tabular}{lcc}
\hline Ingredients & Consumption & Concentration \\
\hline Corn silage & 8.50 & 40.53 \\
Pre-dried silage & 4.85 & 23.13 \\
Wheat straw & 0.36 & 1.72 \\
Soybean meal 46\% & 2.02 & 9.63 \\
Soybean hull & 1.80 & 8.58 \\
Wet brewery waste & 1.05 & 5.01 \\
Corn meal & 0.86 & 4.1 \\
High moisture corn silage & 0.70 & 3.34 \\
Optigen & 0.04 & 0.19 \\
Mineral-vitamin mix & & 3.77 \\
& 0.79 & \\
Nutrients & & 44.55 \\
Dry matter & & 3.07 \\
Ether extract & 9.34 & 1.55 \\
Net energy for lactation, Mcal ${ }^{2}$ & 0.64 & 16.64 \\
Crude protein (CP) & 32.46 & 11.39 \\
Rumen degradable protein & 3.49 & 38.70 \\
Neutral detergent fiber & 2.39 & 18.74 \\
Starch & 8.11 & 0.86 \\
Tryptophan $^{3}$ & 3.93 & \\
\hline
\end{tabular}

${ }^{1}$ Composition (g kg $\left.{ }^{-1} \mathrm{DM}\right): 196 \mathrm{~g} \mathrm{Ca} ; 40 \mathrm{~g} \mathrm{P} ; 32 \mathrm{~g} \mathrm{Mg} ; 16 \mathrm{~g} \mathrm{~S} ; 86 \mathrm{~g} \mathrm{Na} ; 478 \mathrm{mg}$ Mn; 1,451 mg Zn; 330 mg Cu; 2,247 mg Fe; 7 mg Co; 18 mg I; 8 mg Se; 106 IU vitamin A; 32 IU vitamin D; 633 IU vitamin E; 24 g biotin; 250 mg monensin. $\mathrm{kg}^{-1}$. ${ }^{2}$ Concentration: Mcal $\mathrm{kg}^{-1}$.DM. ${ }^{3}$ Concentration: $\%$ of CP. 
The experimental period lasted ten days. The samples were collected during the first two days, without supplementation of vitamins in the diet (without), and during the last two days, eight days after the beginning of the vitamin supplementation (with). Vitamin supplementation included 3 g.cow ${ }^{-1}$. day $^{1}$ of a commercial compound with rumenprotected vitamins (Vivalto, ®Trow Nutrition) and 6 g.cow ${ }^{-1}$.day ${ }^{-1}$ of niacin (Niavit) not protected from ruminal degradation, which was pre-mixed with $141 \mathrm{~g}$ of cornmeal and mixed in with the total diet. Through supplementation, in addition to the 6 g.cow $^{-1}$ of niacin (B3) not protected from ruminal degradation, the following amounts of rumen-protected vitamins were consumed daily (on average): $120 \mathrm{mg}$ of D-pantothenic acid (B5), 76.5 $\mathrm{mg}$ of pyridoxine (B6), $13.05 \mathrm{mg}$ of folic acid (B9), $9.69 \mathrm{mg}$ of biotin (B7), $921 \mathrm{mcg}$ of cyanocobalamin (B12), 4,500 IU of vitamin A, 900 IU of vitamin D3, and 45 IU of vitamin E.

The cows were milked daily between 05:00 a.m. and 05:30 a.m. (night) and between 03:00 p.m. and 03:30 p.m. Samples of milk representative of each milking were collected during the first two days (without) and during the last two days (with) in the pumping of the night and the total daily production (total). Simultaneously with milk sampling, samples of the expansion tanks of the farm, including the total daily milk of 900 cows, were also collected.

Each composite sample was divided into two flasks: one with a volume of $70 \mathrm{~mL}$ and bronopol preservative, used for physicochemical analyses in the Holstein Cattle Breeder Association of Paraná (“Associação Paranaense de Criadores de Bovinos da Raça Holandesa" - APCBRH), the other with a volume of $100 \mathrm{~mL}$ and kept at $-20{ }^{\circ} \mathrm{C}$ for the determination of melatonin concentration. The fat, protein, and lactose contents were determined by infrared spectrophotometry using a Bentley $2000^{\circledR}$ automated equipment (Bentley Instruments Inc.); the urea concentration was analyzed by the Berthelot enzymatic method (BERGMEYER,
1985) and spectrophotometry, using a Chemspec $150^{\circledR}$ equipment (Bentley Instruments Inc.); and the somatic cell count (SCC) was performed by flow cytometry in a Somacount $500^{\circledR}$ equipment (Bentley Instruments Inc.).

Melatonin concentration was determined by enzymeimmunoassayusing the ELISAkit(RE54041, IBL International, Hamburg, Germany), according to Kollmann et al. (2008). Samples were thawed and centrifuged at $3,000 \times g$ for 10 minutes at $4{ }^{\circ} \mathrm{C}$ for fat separation, and the melatonin concentration was determined in the defatted phase. The readings were carried out in a spectrophotometer at $450 \mathrm{~nm}$. The curve adjustment and mathematical model for the determination of the melatonin concentration were performed through logistic regression using patterns with known concentrations, resulting in a coefficient of determination $\left(\mathrm{R}^{2}\right)=0.99$.

The data were analyzed through descriptive statistics. The normality was evaluated with the Kolmogorov-Smirnov test and the analysis of variance with paired data (with and without supplementation of vitamins; total milk and night milk) and Tukey test at $5 \%$ of significance. The Dell Statistica 13.0 software (DELL, 2016) was used for the analysis.

\section{Results and Discussion}

The concentration of melatonin in the total daily milk without dietary vitamin supplementation (3.27 pg. $\mathrm{mL}^{-1}$ ) did not differ from milk produced with supplementation (2.71 pg.mL $\left.\mathrm{m}^{-1}\right)$ and total milk in tanks from the herd of 900 cows (mean of $2.96 \mathrm{pg} \cdot \mathrm{mL}^{-1}$; Figure 1). In the night milk, vitamin supplementation resulted in a melatonin concentration of $40.55 \%$, which was lower than the cow milk Without supplementation (6.57 vs 11.06 pg. $\left.\mathrm{mL}^{-1}\right)$. The maximum concentration of melatonin (25.90 pg. $\mathrm{mL}^{-1}$ ) was observed in the NIGHT milk from cows without vitamin supplementation. 
Figure 1. Means (columns) and 95\% confidence interval (bars) of the melatonin concentration in the total daily milk and night milk from cows with and without dietary vitamins supplementation (A) and total milk of the herd in expansion tanks (B) in the first two days (1) and last two days (2) of the experimental period.
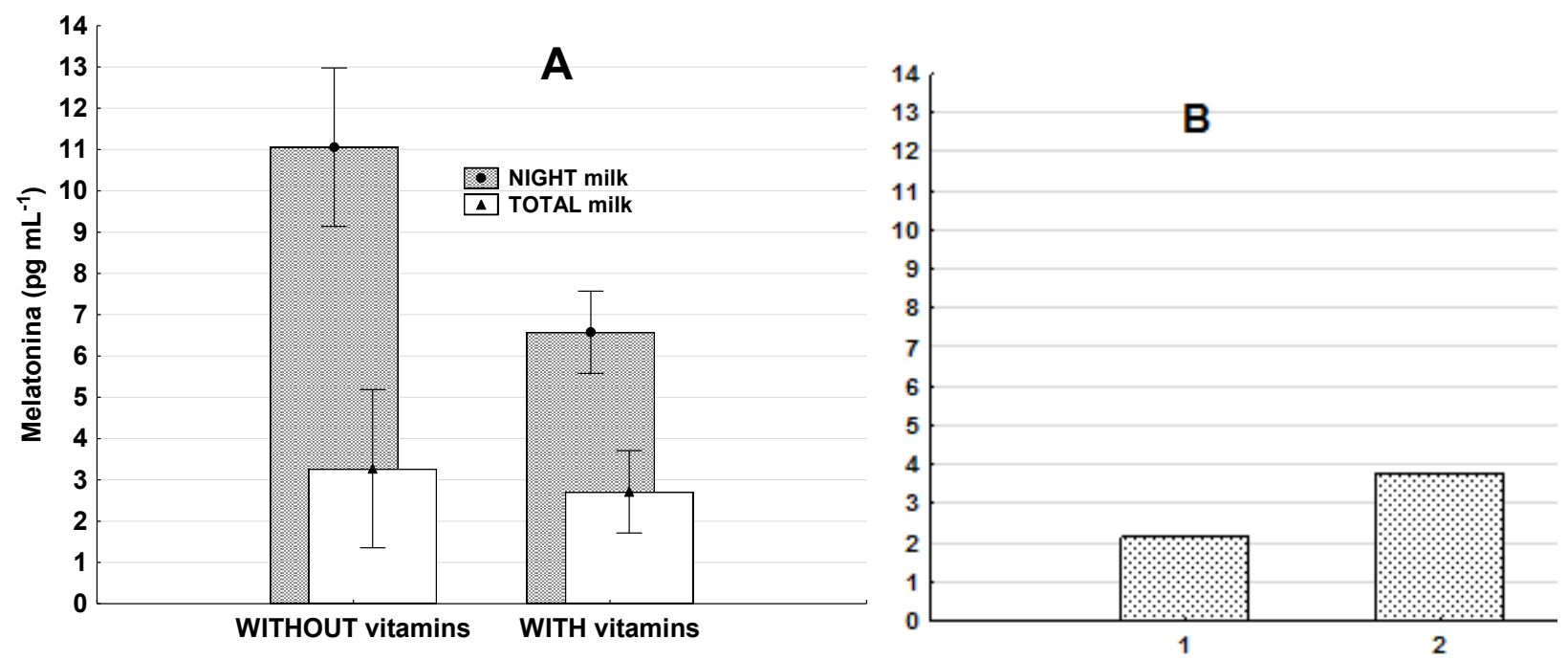

The concentrations of melatonin observed in this study were higher than the mean values of $2.2 \pm 0.5$ pg.mL $\mathrm{m}^{-1}$ and $0.4 \pm 0.2 \mathrm{pg} \cdot \mathrm{mL}^{-1}$ found by Castro et al. (2011), in milk produced at night (11:00 p.m. to 06:00 a.m.) and daytime (08:00 a.m. to 10:00 a.m.), respectively. Kollmann et al. (2008) also found similar concentrations, ranging from $1.8 \mathrm{pg} . \mathrm{mL}^{-1}$ to 4.4 pg.mL $\mathrm{mL}^{-1}$ in milk milked at 3:45 p.m., and 3.9 pg.mL $\mathrm{mL}^{-1}$ to 6.7 pg.mL $\mathrm{m}^{-1}$ in milk milked at 04:45 a.m.

Results indicating possible inhibitory effects of vitamins on the synthesis of melatonin were not found in the literature. Besides, simultaneous supplementation of several vitamins makes it challenging to identify which vitamin had an inhibitory effect and the mechanism by which the inhibition occurred.

The supplemented water-soluble vitamins act as coenzymes and are essential for the metabolic reactions related to melatonin biosynthesis (PEUHKURI et al., 2012). Thus, vitamin supplementation in the diet was performed in this study in order to improve the synthesis of melatonin, as it was expected that in the case of vitamin deficiency, supplementation would produce an increase in their concentration, or, in the case of vitamin sufficiency, only the maintenance of its concentration.

Studies about the effects of nutrients on the synthesis of melatonin have generally been performed with mice and humans. Some studies show a positive impact of the minerals zinc (BELVIRANLI; BALTACI, 2008), magnesium (BILLYARD et al., 2006), and calcium (MORTON, 1989) on melatonin production. Moreover, an increase in the production of melatonin through the supply of vitamins such as folic acid and pyridoxine (SCHERNHAMMER et al., 2009), and n-3 polyunsaturated fatty acids such as docosahexaenoic acid (LAVIALLE et al., 2008) have been detected. Folic acid, pyridoxine, and cyanocobalamin are also essential for the metabolism of homocysteine, which donates a methyl group in the biochemical reactions for the synthesis of melatonin (PEUHKURI et al., 2012).

A possible cause for the decrease of the melatonin concentration in milk with vitamin supplementation could be increased amino acid requirements, including tryptophan, with the eight-day progress of gestation in $68 \%$ of the studied cows, which would decrease their availability for the synthesis 
of melatonin. However, the increase in protein concentration in milk indicated the opposite in this study (Table 2). Besides, high ruminal degradability of dietary niacin, which may reach as high as $90 \%$ (SANTSCHI et al., 2005), and a possible increase in its metabolic requirement (NAD and NADP), may have increased the use of tryptophan for the synthesis of niacin and limited the synthesis of melatonin.
Night milk (05:00 a.m.) had melatonin concentrations between 1.43 (with vitamins) and 2.38 (without vitamins) times higher than total daily milk, showing the influence of the dark period on its synthesis. In the present study, cows were maintained for only eight to nine hours with illuminance up to 0.1 lux (Table 2), that is, within limits that did not inhibit synthesis of melatonin (MUTHURAMALINGAM et al., 2006).

Table 2. Average time (hours) with illuminance $\leq 0.1$ lux (Night) or above 100 lux (Day), and the transition periods night-day (Dawn) and day-night (Dusk) in the free-stall stable during the periods of milk sampling without and with vitamin supplementation for cows.

\begin{tabular}{lccccc}
\hline Supplementation & Night & Day & Transition - Dawn & Transition - Dusk & Total \\
\hline Without & $08: 54$ & $11: 54$ & $02: 30$ & $00: 48$ & $24: 00$ \\
With & $08: 18$ & $12: 24$ & $02: 36$ & $00: 30$ & $24: 00$ \\
\hline
\end{tabular}

According to Muthuramalingam et al. (2006), illuminances between 5 and 10 lux do not affect the synthesis of melatonin, while values of 50 lux inhibit its synthesis by 50\%. Thus, for approximately eight hours in which the illuminance was maintained at $\leq 0.1$ lux, we assumed that there was no inhibition of the synthesis of melatonin due to illuminance. However, conducting this study in the summer resulted in a low number of night hours.

Higher concentrations of melatonin were found in night milk with longer durations of dark periods in previous studies. Valtonen et al. (2001) detected an increase from $10 \mathrm{pg} . \mathrm{mL}^{-1}$ to $60 \mathrm{pg} \cdot \mathrm{mL}^{-1}$ in melatonin concentration when they increased the dark period from 12 to 17 hours/day. Asher et al. (2015) found $30.70 \pm 1.79$ pg.mL $\mathrm{mL}^{-1}$ of melatonin in the milk of cows kept at 13 hours with illuminance up to 5.08 \pm 0.04 lux. Milagres et al. (2014) found melatonin concentrations of 39.43 pg.mL $\mathrm{m}^{-1}$ in milk milked at 02:00 a.m. and 4.03 pg. $\mathrm{mL}^{-1}$ in milk milked at 03:00 a.m., in a study performed in June, when the night lasts for longer.

Thus, we hypothesize that the short duration of the dark period, with illuminance $\leq 0.1$ lux, limited the concentration of melatonin in milk milked at night. Besides, when the duration of the night is longer, during the winter, night milk may contain a higher concentration of melatonin.

The performance of only two daily milkings, with an interval of approximately four hours after the milking of the afternoon (03:00 p.m.) until early evening (dark period), and with an illuminance above 100 lux, may also have contributed to the low concentration of melatonin in night milk. With such an illuminance value, the synthesis of melatonin is insignificant and, consequently, the low-melatonin secreted milk at this time had a dilutive effect on the milk secreted at night. A scheme planned for milking near the early and late night (dark period) may increase the concentration of melatonin in the milk from the milking of the end of the night.

Overall, the concentration of components in milk allowed us to hypothesize that there were no shortages of nutrients for the melatonin synthesis in the metabolism, including amino acids for protein synthesis (Table 3). Among them is tryptophan, which is the precursor of the synthesis of melatonin. 
Table 3. Means and standard deviations $( \pm)$ of daily milk production of $\operatorname{cow}^{-1}$.day ${ }^{-1}$ and the concentrations of components in the total daily milk of cows without and with vitamin supplementation in the diet, and milk from the total herd (Tanks).

\begin{tabular}{lccc}
\hline \multirow{2}{*}{ Parameter } & \multicolumn{2}{c}{ Supplementation ${ }^{1,2}$} & \multirow{2}{*}{ Tanks } \\
\cline { 2 - 3 } & Without & With & \\
\hline $\mathrm{N}$ & 21 & 21 & - \\
Milk, kg & $22.79 \pm 3.14$ & $23.06 \pm 3.16$ & $3.37 \pm 0.18$ \\
Fat, \% & $4.12 \pm 0.93$ & $3.89 \pm 0.62$ & $3.09 \pm 0.02$ \\
Protein, \% & $3.40 \pm 0.30$ & $3.38 \pm 0.57$ & $4.62 \pm 0.02$ \\
Lactose, \% & $4.39 \pm 0.34$ & $4.23 \pm 0.44$ & $11.99 \pm 0.23$ \\
Total Solids, \% & $12.84 \pm 1.30$ & $12.41 \pm 1.38$ & $10.84 \pm 0.74$ \\
Urea $^{3}$ & $12.05 \pm 2.52^{\mathrm{b}}$ & $14.78 \pm 4.74^{\mathrm{a}}$ & 209.20 \\
SCC $^{4}, \times 1,000 \mathrm{~mL}^{-1}$ & 134.39 & 107.86 & \\
\hline
\end{tabular}

${ }^{1}$ Supplemented vitamins of $\mathrm{cow}^{-1}$.day $^{-1}: 120 \mathrm{mg}$ d-pantothenic acid; $76.5 \mathrm{mg}$ pyridoxine; $13.05 \mathrm{mg}$ folic acid; $9.69 \mathrm{mg}$ biotin; 921 mg cyanocobalamin; 4,500 IU vitamin A; $900 \mathrm{IU}$ vitamin $\mathrm{D}_{3}$; 45 IU vitamin E, rumen-protected; $6 \mathrm{~g}$ niacin, not protected from ruminal degradation.

${ }^{2}$ Means with different letters on the same line differ with $5 \%$ of significance.

${ }^{3} \mathrm{mg} \cdot \mathrm{dL}^{-1}$.

${ }^{4}$ geometric mean.

The contents of the different components found in the experimental cow milk and the expansion tank were in line with the Brazilian legislation (BRASIL, 2011). They were also similar to those observed by Ribas et al. (2014), who studied $1,950,034$ milk samples in expansion tanks in the state of Paraná and found $3.74 \pm 0.69 \%$ of fat, 3.22 $\pm 0.27 \%$ of proteins, $4.40 \pm 0.23 \%$ of lactose, and $12.29 \pm 0.85 \%$ of total solids.

The nutrient contents did not differ between milk with and without vitamin supplementation in the diet, suggesting that their availability in the metabolism did not limit their synthesis. Sacadura et al. (2008) supplemented cows producing $40 \mathrm{~kg}$.day ${ }^{-1}$ of milk with $3 \mathrm{~g}$ of a mixture of rumen-protected $\mathrm{B}$ vitamins in the diet and observed an increase in protein production (1.21 vs $1.24 \mathrm{~kg}$.day ${ }^{-1}$ ) and a decrease of fat content (3.71 vs 3.63\%) in the milk of 247 cows with $218.8 \pm 3.90$ days of lactation, concluding that supplementation increased metabolic efficiency.

The levels of urea in milk are indicators of protein nutrition. The values found in this study (Table 3) are close to the suggested limits of $10 \mathrm{mg} \cdot \mathrm{dL}^{-1}$ and $14 \mathrm{mg} \cdot \mathrm{dL}^{-1}$, which indicate adequate protein nutrition (MUNYANEZA et al., 2017). These values were similar to the mean of $14.18 \mathrm{mg}^{\mathrm{d} \mathrm{dL}^{-1}}$ found by Doska et al. (2012) in 127,428 samples of Holstein cow milk in 96 herds in the state of Paraná. The higher value of urea concentration in milk with vitamin supplementation suggests that these cows had an excess of ammonia in ruminal fermentation, or increased catabolism of amino acids in the metabolism (SPEK et al., 2013).

The SCC indicates the health of the mammary glands of the experimental cows, and this variable did not differ with vitamin supplementation. The observed values are in line with the requirements of the Brazilian legislation (max. 400 thousand.mL$\left.{ }^{1}\right)$ and are lower than the average of 553 thousand $\mathrm{mL}^{-1}$ found by Ribas et al. (2014) in 1,950,034 milk samples from the state of Paraná.

To evaluate the effects of consumption of melatonin-rich milk in humans, Valtonen et al. (2005) offered 0.61 1.day ${ }^{-1}$ of milk with a melatonin concentration of $15.3 \pm 3.1 \mathrm{pg} . \mathrm{mL}^{-1}$ to 81 seniors with a mean age of 82 years and observed improvements 
in their sleep quality and activity level. Recently, Bae et al. (2016) found greater satisfaction with sleep and decreased daytime sleepiness in young people with mild insomnia symptoms after providing night milk in an amount that contained $1,000 \mathrm{pg}$ of melatonin and $58.24 \mathrm{mg}$ of tryptophan, which are high values when compared to the total daily milk (usual; $100 \mathrm{pg}$ of melatonin and $47.5 \mathrm{mg}$ of tryptophan). The amount of melatonin supplied through night milk in the study by Bae et al. (2016) is equivalent to $130 \mathrm{~mL}$ of night milk from cows without vitamins from the present study.

\section{Conclusions}

Under the conditions of the present study, dietary supplementation with niacin unprotected from ruminal degradation for cows in the final lactation period, as well as the vitamins pyridoxine, cyanocobalamin, folic acid, biotin, pantothenic acid, vitamin $A$, vitamin $D$, and vitamin $E$ protected from ruminal degradation, decreased the concentration of melatonin in milk milked at the end of the dark period.

Milk from cows without vitamin supplementation milked at the end of the dark period (night), with an illuminance $\leq 0.1$ lux for eight and a half hours, had a melatonin concentration 2.38 times higher than the total daily milk. Thus, a differentiated sampling of the milk from the milking of the end of the dark period makes it possible to obtain and commercialize milk rich in melatonin, with potential health benefits for consumers.

\section{Acknowledgments}

The authors thank the Holstein Cattle Breeder Association of Paraná ("Associação Paranaense de Criadores de Bovinos da Raça Holandesa" APCBRH) for performing the physical-chemical analyses and MSc. Rafael Luiz Venâncio for contributing in the analysis for the determination of melatonin in milk.

\section{References}

ASHER, A.; SHABTAY, A.; BROSH, A.; EITAM, H.; AGMON, R.; COHEN-ZINDER, M.; ZUBIDAT, A. E.; HAIM, A. Chrono-functional milk: the difference between melatonin concentrations in night-milk versus day-milk under different night illumination conditions. Chronobiologyinternational, London, v. 32, n. 10, p. 14091416, 2015. DOI: 10.3109/07420528.2015.1102149.

BAE, S. M.; JEONG, J.; JEON, H. J.; BANG, Y. R.; YOON, I. Effects of melatonin-rich milk on mild insomnia symptoms. Sleep Medicine Research, Ansan, v. 7, n. 2, p. 60-67, 2016. DOI: 10.17241/smr.2016.00108.

BELVIRANLI, M.; BALTACI, A. K. The relation between reduced serum melatonin levels and zinc in rats with induced hypothyroidism. Cell biochemistry and function, Guildford, v. 26, n. 1, p. 19-23, 2008. DOI: 10.1002/cbf.1384.

BERGMEYER, H. U. Methods of enzymatic analysis. Florida: VHC, 1985. $453 \mathrm{p}$.

BHAT, Z. F.; BHAT, H. Milk and dairy products as functional foods: a review. International Journal of Dairy Science, Faisalabad, v. 6, n. 1, p. 1-12, 2011. DOI: 10.3923/ijds.2011.1.12

BILLYARD, A. J.; EGGETT, D. L.; FRANZ, K. B. Dietary magnesium deficiency decreases plasma melatonin in rats. Magnesium research, London, v. 19, n. 3, p. 157-161, 2006. DOI: 10.1684/mrh.2006.0002.

BRASIL. Instrução Normativa no 62, de 30 de dezembro de 2011. Aprova os regulamentos técnicos de composição e requisitos físicos, químicos e microbiológicos do Leite... Diário Oficial [da] União, Brasília, 31 dez. 2011. Seção 1, p. 6.

CASTRO, N.; SPENGLER, M.; LOLLIVER, V.; WELLNITZ, O.; MEYER, H. H. D.; BRUCKMAIER, R. M. Diurnal pattern of melatonin in blood and milk of dairy cows. Milchwissenschaft, Kempten, v. 66, n. 4, p. 352-353, 2011

DAWN, M. R.; DAWES, M. A.; MATHIAS, C. W.; ACHESON, A.; HILL-KAPTURCZAK, N.; DOUGHERTY, D. M. L-tryptophan: basic metabolic functions, behavioral research and therapeutic indications. International Journal of Tryptophan Research, Auckland, v. 23 , n. 2, p. 45-60, 2009. Available at: https://www.ncbi. nlm.nih.gov/pmc/articles/PMC2908021/.

DELL. Dell Statistica: data analysis software system. Version 13. Tulsa: Dell Inc., 2016.

DIBELLA, G.; MASCIA, F.; GUALANO, L.; DIBELLA, L. Melatonin anticancer effects: review. International 
Journal of Molecular Science, Basel, v. 14, n. 2, p. 24102430, 2013. DOI: $10.3390 \% 2 F i j m s 14022410$.

DOSKA, M. C.; SILVA, D. F. F.; HORST, J. A.; VALLOTO, A. A.; ROSSI JUNIOR, P.; ALMEIDA, R. Sources of variation in milk urea nitrogen in Paraná dairy cows. Revista Brasileira de Zootecnia, Viçosa, MG, v. 41, n. 3, p. 692-697, 2012. DOI: 10.1590/S151635982012000300032 .

HOFMAN, M. A.; SKENE, D. J.; SWAAB, D. F. Effect of photoperiod on the diurnal melatonin and 5-methoxytryptophol rhythms in the human pineal gland. Brain Research, Amsterdam, v. 671, n. 2, p. 254-260, 1995. DOI: 10.1016/0006-8993(94)01339-J.

KOLLMANN, M. T.; LOCKER, M.; HIRCHE, F.; EDER, K.; MEYER, H. H.; BRUCKMAIER, R. M. Effect of tryptophan supplementation on plasma-tryptophan and related hormone levels in heifers and dairy cows. Domestic Animal Endocrinology, Stoneham, v. 34, n. 1, p. 14-24, 2008. DOI: 10.1016/j.domaniend.2006.09.005.

LAVIALLE, M.; CHAMPEIL-POTOKAR, G.; ALESSANDRI, J. M.; BALASSE, L.; GUESNET, P.; PAPILLON, C.; PÉVET, P.; VANCASSEL, S.; VIVIENROELS, B.; DENIS, I. An (n-3) polyunsaturated fatty acid-deficient diet disturbs daily locomotor activity, melatonin rhythm, and striatal dopamine in Syrian hamsters. Journal of Nutrition, Rockville, v. 139, n. 9, p. 1719-1724, 2008. DOI: 10.1093/jn/138.9.1719.

MARIA, C. A. B.; MOREIRA, R. F. A. A intrigante bioquímica da niacina - uma revisão crítica. Química Nova, São Paulo, v. 34, n. 10, p. 1739-1752, 2011. DOI: 10.1590/S0100-40422011001000007.

MILAGRES, M. P.; MININ, V. P. R.; MININ, L. A.; SIMIQUELI, A. A.; MORAES, L. E. S.; MARTINO, S. D. Night milking adds value to cow's milk. Journal of Science of Food and Agriculture, London, v. 94, n. 8, p. 1688-1692, 2014. DOI: 10.1002/jsfa.6480.

MORTON, D. J. Possible mechanisms of inhibition and activation of rat $\mathrm{N}$-acetyltransferase (EC 2.3.1.5.) by cations. Journal of neural transmission, Wien, v. 75, n. 1, p. 51-64, 1989.

MUNYANEZA, N.; NIYUKURI, J.; EL HACHIMI, Y. Milk urea nitrogen as an indicator of nitrogen metabolism efficiency in dairy cows: a review. Theriogenology Insight, New Delhi, v. 7, n. 3, p. 45-159, 2017. DOI: 10.5958/2277-3371.2017.00032.8

MUTHURAMALINGAM, P.; KENNEDY, A. D.; BERRY, R. J. Plasma melatonin and insulin-like growth factor-1 responses to dim light at night in dairy heifers. Journal of Pineal Research, Oxford, v. 40, n. 3, p. 225229, 2006. DOI: 10.1111/j.1600-079X.2005.00303.x.
PEUHKURI, K.; SIHVOLA, N.; KORPELA, R. Dietary factors and fluctuating levels of melatonin. Food \& Nutrition Research, Balsia, v. 56, p. 1-9, 2012. DOI: $10.3402 \% 2$ Ffnr.v56i0.17252

RIBAS, N. P.; ROSSI JUNIOR, P.; ANDRADE, U. V. C.; VALLOTO, A. A.; JESUS, C. P.; ALMEIDA, M. C. Escore de células somáticas e sua relação com os componentes do leite em amostras de tanque no estado do paraná. Archives of Veterinary Science, Curitiba, v. 19, n. 3, p. 14-23, 2014.

RICHARD, D. M.; DAWES, M. A.; MATHIAS, C. W.; ACHESON, A.; HILL-KAPTURCZAK, N.; DOUGHERTY, D. M. L-Tryptophan: basic metabolic functions, behavioral research and therapeutic indications. International Journal of Tryptophan Research, Auckland, v. 2, p. 45-60, 2009.

SACADURA, F. C.; ROBINSON, P. H.; EVANS, F.; LORDELO, M. Effects of a ruminally protected B-vitamin supplement on milk yield and composition of lactating dairy cows. Animal Feed Science and Technology, Amsterdam, v. 144, n. 1-2, p. 111-124, 2008. DOI: $10.1016 / j$.anifeedsci.2007.10.005

SANTSCHI, D. E.; BERTHIAUME, R.; MATTE, J. J.; MUSTAFA, A. F.; GIRARD, C. L. Fate of supplementary B-vitamins in the gastro-intestinal tract of dairy cows. Journal of Dairy Science, Champaign, v. 88, n. 6, p. 20432054, 2005. DOI: 10.3168/jds.S0022-0302(05)72881-2

SCHERNHAMMER, E. S.; FESKANICH, D.; NIU, C.; DOPFEL, R.; HOLEMS, M. D.; HANKINSON, S. E. Dietary correlates of urinary 6- sulfatoxymelatonin concentrations in the Nurses' Health Study cohorts. American Journal of Clinical Nutrition, Bethesda, v. 90, n. 4, p. $975-985$, 2009. DOI: $10.3945 /$ ajcn.2009.27826

SPEK, J. W.; DIJKSTRA, J.; VAN DUINKERKEN, G.; BANNINK, A. A review of factors influencing milk urea concentration and its relationship with urinary urea excretion in lactating dairy cattle. Journal of Agricultural Science, London, v. 151 , n. 3, p. 407-423, 2013. DOI: $10.1017 /$ S0021859612000561

STANTON, C.; MCMAHON, D.; MILLS, S. Dairy components, products and human health. In: MUEHLHOFF, E.; BENNETT, A.; MCMAHON, D. (Ed.). Milk and dairy products in human nutrition. Rome: Food and Agriculture Organization of United Nations, cap. 5, p. 207-242, 2013.

VALTONEN, M.; KANGAS, A. P.; VOUTILAINEN, M. Method for producing melatonin rich milk. Patent Cooperation Treaty WO, International Publication Number WO 01/01784 A1, Stockholm, Sweden, 2001. $6 \mathrm{p}$. 
VALTONEN, M.; NISKANEN, L.; KANGAS, A.; WIJESINHA-BETTONI, R.; BURLINGAME, B. Milk KOSKINEN, T. Effect of melatonin-rich night-time milk and dairy product composition. In: MUEHLHOFF, E.; on sleep and activity in elderly institutionalized subjects. Nordic Journal of Psychiatry, Boston, v. 59, n. 3, p. 217221, 2005. DOI: 10.1080/08039480510023034 BENNETT, A.; MCMAHON, D. (Ed.). Milk and dairy products in human nutrition. Rome: Food and Agriculture Organization of United Nations, cap. 3, p. 41-102, 2013. 